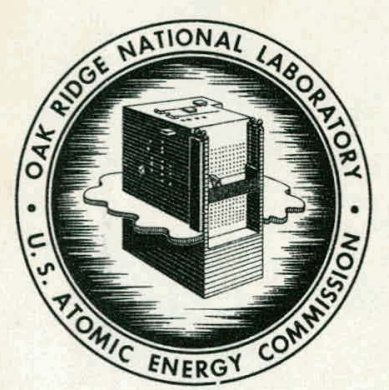

DATE:

\section{OAK RIDGE NATIONAL LABORATORY}

Operated by UNION CARBIDE NUCLEAR COMPANY

Division of Union Carbide Corporation

\section{UCC}

Post Office Box $X$

Oak Ridge, Tennessee

SUBJECT: Leybold DO-4001 - Oil Diffusion Pump

TO:

\title{
C.E. Normand
}

FROM:

ORNL
CENTRAL FILES NUMBER
$59-6-76$

COPY NO. 38

\section{NOTICE}

This document contains information of a preliminary nature and was prepared primarily for internal use at the Oak Ridge National Laboratory. It is subject to revision or correction and therefore does not represent a final report. The information is not to be abstracted, reprinted or otherwise given public dissemination without the approval of the ORNL patent branch, Legal and Information Control Department. 


\section{DISCLAIMER}

This report was prepared as an account of work sponsored by an agency of the United States Government. Neither the United States Government nor any agency Thereof, nor any of their employees, makes any warranty, express or implied, or assumes any legal liability or responsibility for the accuracy, completeness, or usefulness of any information, apparatus, product, or process disclosed, or represents that its use would not infringe privately owned rights. Reference herein to any specific commercial product, process, or service by trade name, trademark, manufacturer, or otherwise does not necessarily constitute or imply its endorsement, recommendation, or favoring by the United States Government or any agency thereof. The views and opinions of authors expressed herein do not necessarily state or reflect those of the United States Government or any agency thereof. 


\section{DISCLAIMER}

Portions of this document may be illegible in electronic image products. Images are produced from the best available original document. 


\section{LEYBOID DO-4001}

OIL DIFFUSION PUMP:

C. E. Normand

This report summarizes results of tests run on a Leybold D0-4001 (14 in.) oll diffusion pump.

The test facility and instrumentation are shown schematically in Fig. i. Octoil-s pump fluid was used throughout the tests.

Tests were first run on the unbaffled pump, then on the pump with matching water-cooled baffle.

1. Operating power. The pump was operated at powers ranging from less than 1000 to above 4000 watts, (nominal, $3000 \mathrm{w}$ ). Pumping speed (for air) varies only slightly over this power range. At less than 1500 watts the ultimate pressure is lowest and pressure variations are least; but limiting fore pressure, and, therefore, gas handing capacity, is low. From 1500 to 3000 watts the ultimate pressure rises slightly, and pressure variation becomes progressively more prounced; but limiting fore pressure rises to near its maximum value. Above 3000 watts the ultimate pressure remains essentially constant, pressure oscillations become continuous but of smaller amplitude, and limiting fore pressure rises only slightly.

There is no clearly defined optimum operating power. The 3000 watts recommended by the supplier gives near minimum pressure and near maximum limiting fore pressure; it does, however, put operation in the range of most pronounced pressure variation.

2. Pumping speed. Pumping speeds were measured over the $10^{-6}$ to $10^{-4}$ $\mathrm{mm}$ power range for air and hydrogen; with and without baffle, and at a number of operating powers. All speed measurements were by the metered leak method, using oil manometers. The speeds derived are speeds of pumping from the vacuum chamber.

The results are shown in the speed vs. power curves of Fig. 2 


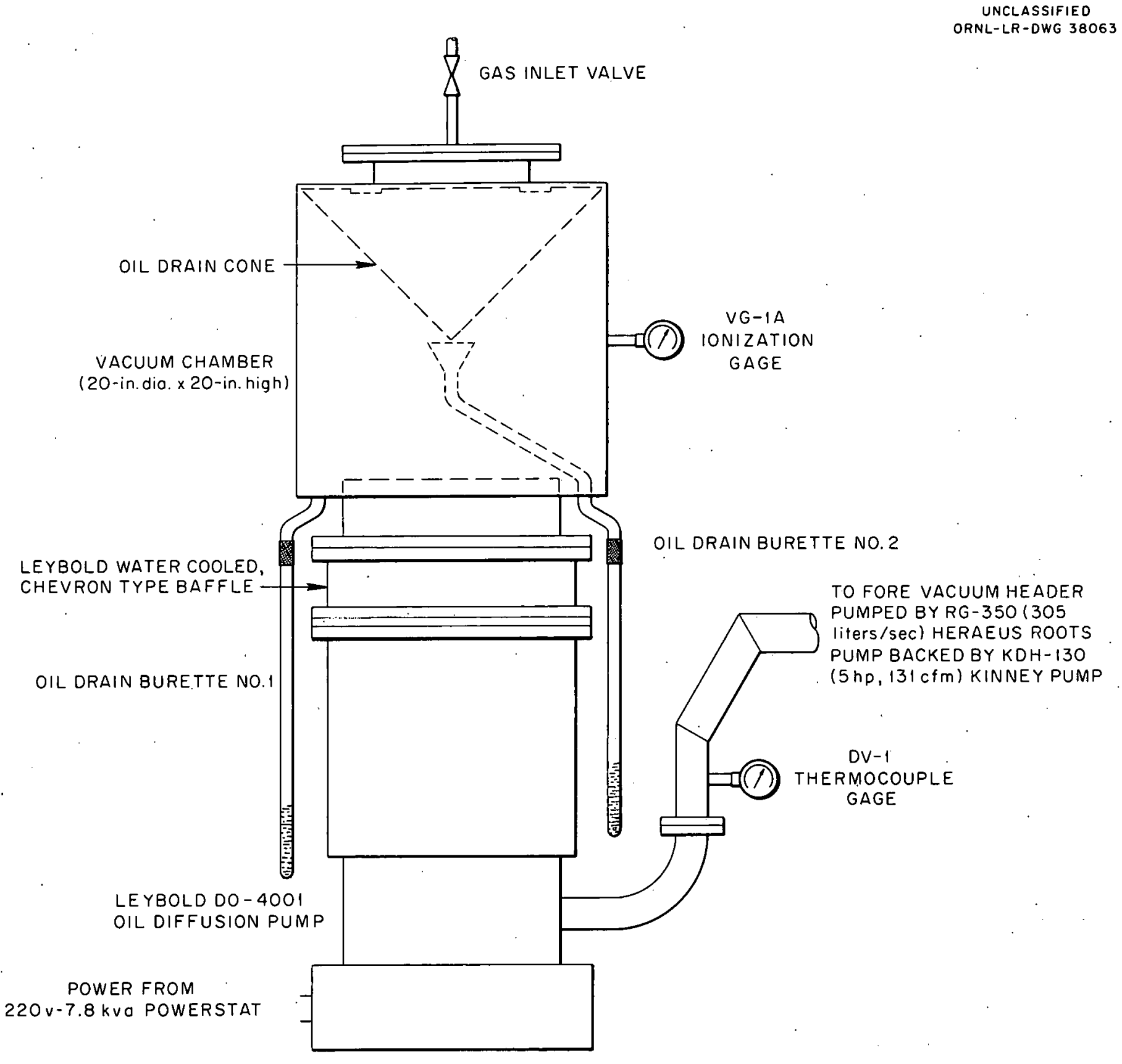

Fig. 1 




Fig. 2. Pumping Speed for Air at Powers Indicated. 


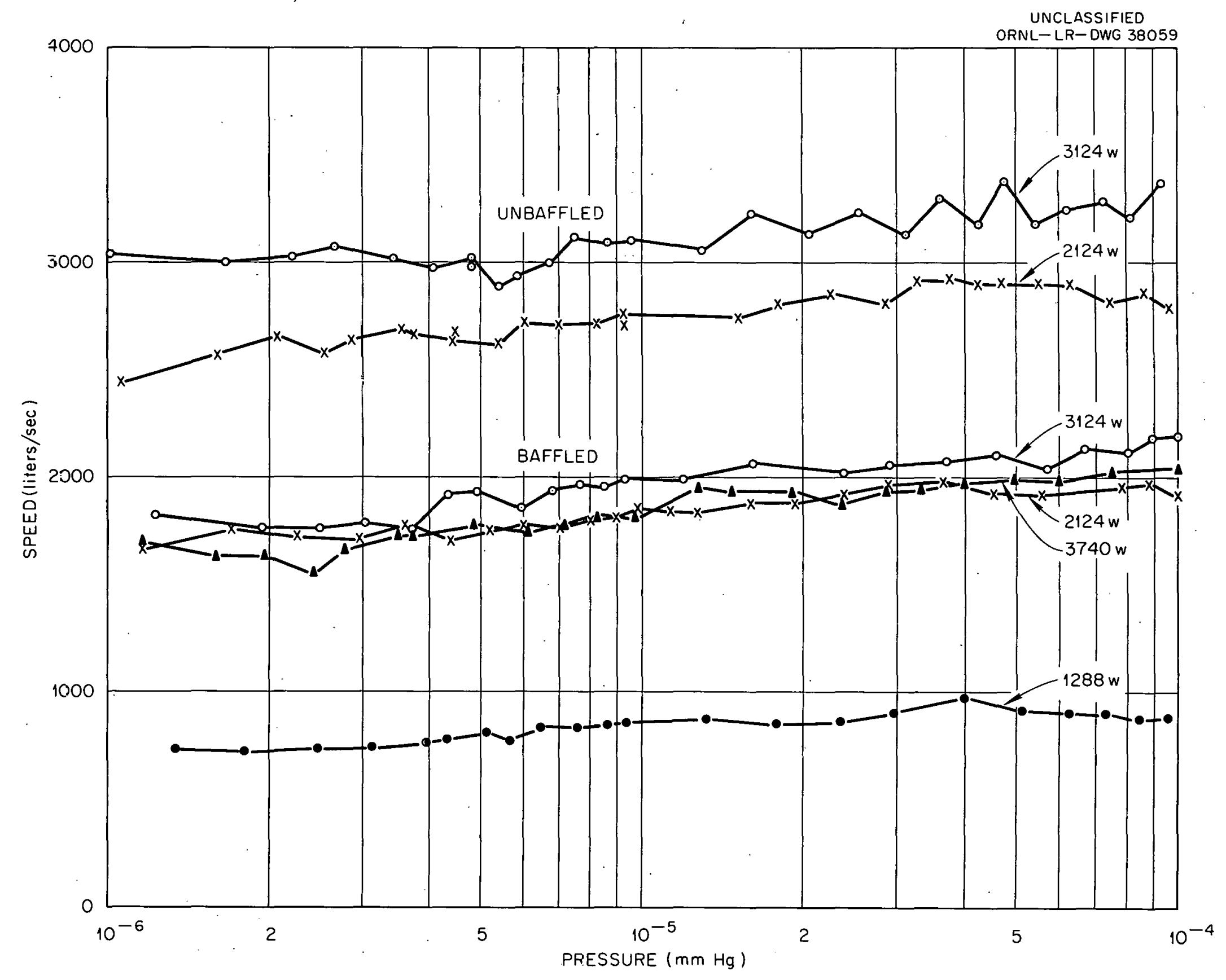

Fig. 3. Pumping Speed for $\mathrm{H}_{2}$ at Powers Indicated. 
and 3. Since speed varies only slightly and almost linearly with pressure in all cases, comparisons may be drawn between average speeds derived from different sets of measurements. These average speeds are listed for comparison in Table I.

TABLE I

AVERAGE PUMPTING SPEED ÁT $10^{-4}$ TO $10^{-6} \mathrm{~mm}$ PRESSURE

\begin{tabular}{|c|c|c|c|c|c|c|}
\hline $\begin{array}{c}\text { Date of } \\
\text { Test }\end{array}$ & Baffle & Gas & $\begin{array}{c}\text { Power } \\
\text { (Watts) }\end{array}$ & $\begin{array}{l}\text { Av. Speed } \\
(\mathrm{L} / \mathrm{Sec} .)\end{array}$ & $\begin{array}{l}\text { Ratio } \\
\text { S H/S Air }\end{array}$ & $\begin{array}{l}\text { Rạtio } \\
\text { S Baf. } \\
\text { S Unbaf }\end{array}$ \\
\hline $1-13$ & No & Air & 2124 & 2982 & & .45 \\
\hline $1-13$ & No & Air & 3052 & 3072 & & .44 \\
\hline$\$-14$ & No & $\mathrm{H}_{2}$ & 2124 & 2747 & .92 & .66 \\
\hline $1-14$ & No & $\mathrm{H}_{2}$ & 3124 & 3128 & 1.02 & .64 \\
\hline $2-3$ & Yes & Air & 1288 & 1207 & & \\
\hline $\begin{array}{l}1-20 * \\
1-27\end{array}$ & Yes & Air & 2124 & 1342 & & \\
\hline $\begin{array}{l}1-20 * \\
1-27\end{array}$ & Yes. & Air & 3134 & 1364 & & \\
\hline $1-23$ & Yes & Air & 3720 & 1316 & & \\
\hline $2-3$ & Yes & $\mathrm{H}_{2}$ & $1288^{\circ}$. & 826 & .68 & \\
\hline $\begin{array}{l}1-16 * \\
1-29\end{array}$ & Yes & $\mathrm{H}_{2}$ & 2124 & $i 825$ & $1: 36^{\circ}$ & \\
\hline $\begin{array}{l}1-16^{*} \\
1-29\end{array}$ & Yes & $\mathrm{H}_{2}$ & 3124 & 2000 & 1.46 & \\
\hline 1-29 & Yes & $\mathrm{H}_{2}$ & 3720 & .1842 & 1.40 & \\
\hline
\end{tabular}

*Average of two series

Comparing the unbaffled pumping speed for air (about $3000 \mathrm{~L} / \mathrm{sec}$ ) with the rated speed of the pump $(4000 \mathrm{~L} / \mathrm{sec})$ suggests that this latter value applies to the blanked off pump. If this is the case, the pump aperture conductance $(11,180 \mathrm{~L} / \mathrm{sec})$ would reduce the speed of pumping from a chamber to a valve such that

$$
\begin{aligned}
\text { or } & \frac{1}{S}=\frac{1}{4000}+\frac{1}{11,180} \\
& S=2964 \mathrm{~L} / \text { sec. } .
\end{aligned}
$$

which is in good agreement with the speed as measured. 




Fig. 4. Limiting Fore Pressure vs. Power Input (Charts.1-10-59 and 1-28-59) 


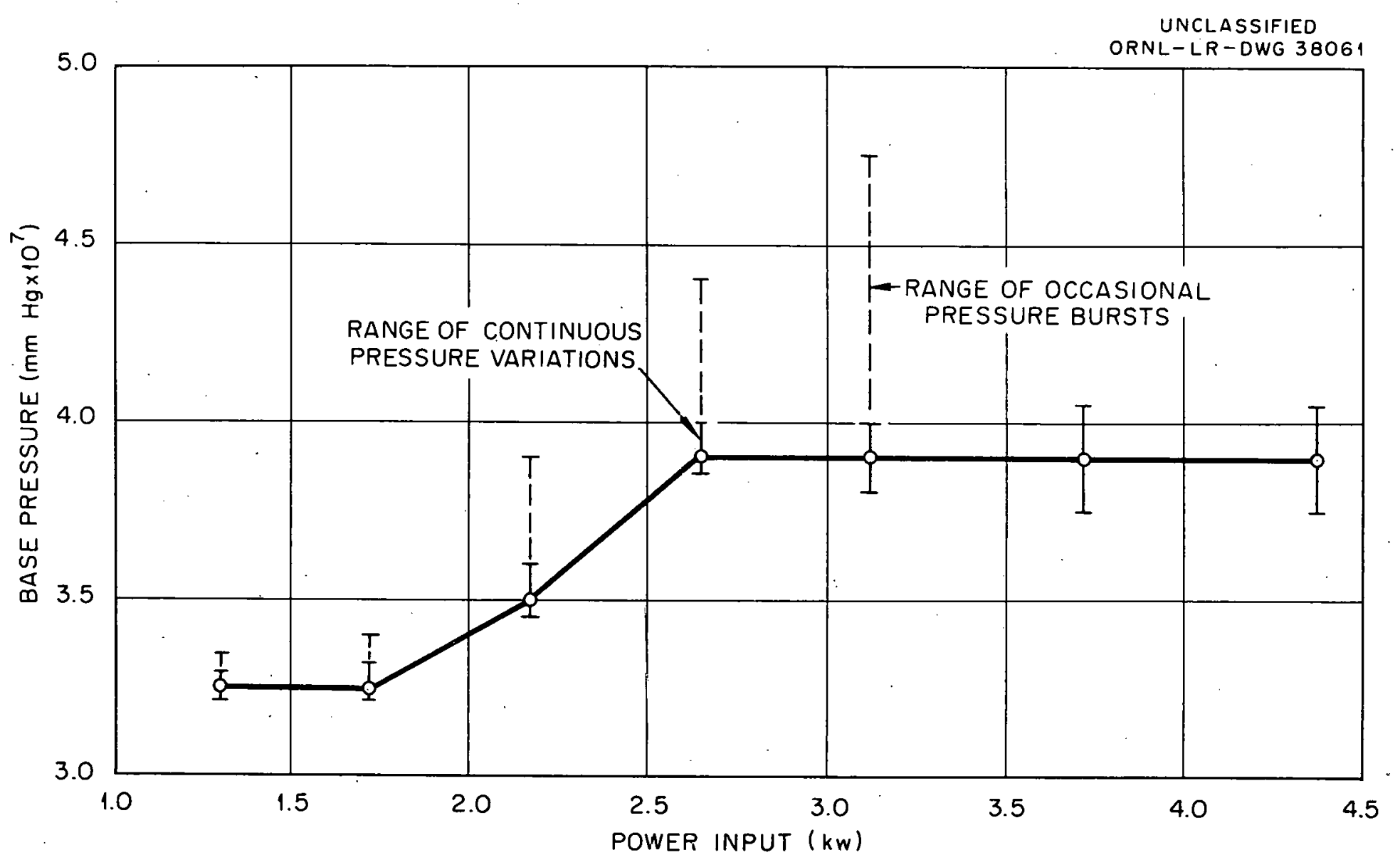

Fig. 5. Base Pressure vs. Power Input.( Chart 2-5-59) 
The Leybold baffle reduced the pumping speed for air by 55 per cent - about par for an optically opaque baffle. For hydrogen, the reduction is only 35 per cent due to the higher conductance of the baffle for hydrogen, ( $\mathrm{oc} I$ ).

The pumping speed for hydrogen is suprisingly low as compared with that for air. This is expected if the power input is low, but even at the highest powers applied, the speed is littie different for the two gases. The whole question of hydrogen versus air pumping speed is being further investigated.

The variation of pumping speed with power input is insignificant in the case of air, except at the lowest power (1288 w) where a real decrease of some 10 per cent appears to occur. In the case of hydrogen the speed variation is somewhat greater, but still rather unimportant, at the higher powers (2100-3700 w). At 1288 watts, however, the speed drops by more than 50 per cent.

3. Limiting Fore Pressure. Limiting static forepressure is plotted as a function of power input in Fig. 4. (Two series taken with different fore-vacuum lines and different locations of the thermocouple gage). Three significant facts are indicated:

a. The limiting fore pressure is never greater than $110 \mu$.

b. Increasing the power above $3000 \mathrm{w}$ results in little improvement in limiting fore pressure:

c. Reducing the power below $3000 \mathrm{w}$ results in a sharp decrease in limiting fore pressure.

4. Uitimate Pressure. Throughout the test period, base pressures of 3 to $4 \times 10^{-7} \mathrm{~mm}$ were consistently obtained in the test chamber. The chamber is of stainless steel, has copper gaskets, and is unbaked and untrapped. The system was first run without baffle, and was not cleaned of oil which diffused into the chamber during this period.

The variation of base pressure with power input is shown in Fig. 5. The approximate range of pressure variation at each power is also indicated.

As compared with other pumps tested; the effect of power on ultimate pressure is very small. 
5. Pressure Variations. As with other pumps tested, the base pressure under constant operating conditions is never quite constant; but varies according to a number of patterns characteristic of different operating powers. Representative pressure traces at different power inputs are shown in Fig. 6.

It will be noted that at yery low powers the pressure is relatively unvarying; at very high powers; the pressure varies rapidly and continuously through a fairly narrow range; at intermediate powers pressure variations are intermittent, but of considerable amplitude.

It is quite apparent that some---and possibly all---of these pressure variations result from particular modes of boiling. At low power, bolling is quiet - no audible indication. At high power, a continual "frying" sound is produced in the pump boiler. At intermediate power, each large pressure burst can be identified with a sound of "explosive" boiling.

6. Oil backstreaming. During the initial week of operation the pump was run without baffle. Power was varied during this period, but most of the time operation was in the 2100 to 3100 watt range. During the final 6\% hours, oil was oraining from the "drip cone" at an essentially constant rate of $0.54 \mathrm{cc} / \mathrm{hr}$. During this same period, no drainage from the chamber wall was observed.

This measured value of backstreaming rate $(.054 \mathrm{cc} / \mathrm{hr}$.$) is$ probably on the low side since the pump was not operated continuously at its rated power; also, it is possible that true equilibrium between backstreaming and drainage had not been reached.

Since the Leybold baffle was installed (about a month) no measurable drainage of oil has occurred. It can be safely said that backstreaming through the baffle is less than a few tenths of a cc per month.

7. Summary. Operating characteristics of the Leybold DO-4001 pump are summarized in Table II, column 1. Characteristics of three other pumps are also tabulated for comparison.

On the basis of these comparisons, the Leybold pump rates well, except for its rather low limiting fore pressure. This feature suggests that in applications demanding large gas handling capacity, this pump should be followed by a booster pump or by a blower---Kinney type combination of backing pumps. 


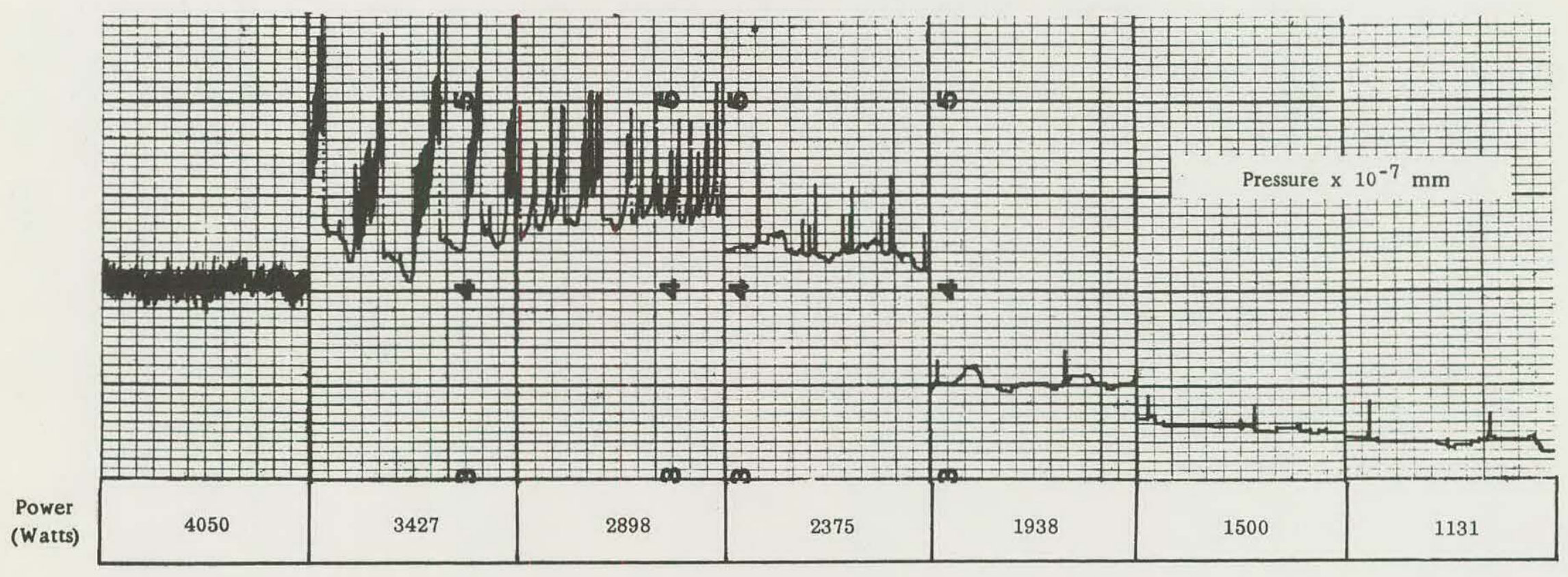

FIGURE 6. TYPICAL PRESSURE TRACES AT DIFFERENT POWER INPUTS 
TABLE II

SIMMARY OF PUMP CHARACTERISTICS

Leybold (1)

DO-4001

$$
\begin{gathered}
W \text {-house } \\
\operatorname{DPI}(2)
\end{gathered}
$$
$20^{n-}-8^{\prime \prime}$

$$
3050
$$

6300

110

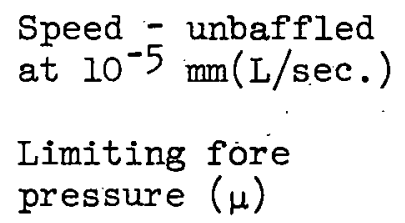

1350

140

400
Consolidated (4) PMC-144D

$$
920
$$

011 Back Str.

Rate (cc/Hr.)

$$
>.054
$$

$-\quad>.077$

.043

\begin{tabular}{llccc}
\hline $\begin{array}{l}\text { Ratio : Speed } \\
\text { To Aperture }\end{array}$ & 19.8 & 20.1 & 17.1 & 22.3 \\
\hline $\begin{array}{l}\text { Ratio : Speed } \\
\text { to Power }\end{array}$ & 1017 & 1016 & 466 & 511 \\
\hline
\end{tabular}

* Ovserved base pressures are not strictly comparable since they do not necessarliy represent true ultimate pressures.

As desirable features of design and construction one might list:

a. Small over-all dimensions.

b. Ruggedness without excessive weight.

c. Precision of fit, spacings, and alignments.

d. Floating flanges.

e. Cast aluminum base on jet assembly.

f. Heat-up and cool-down times are short for a pump of this size.

Whether the cooling water jacket is superior to the more commonly used coolcoils is not apparent. 